\title{
B.M. Рынков
}

\section{ГЕОПОЛИТИЧЕСКИЕ ВЫЗОВЫ И МОДЕРНИЗАЦИОННЫЕ ОТВЕТЫ: ЖЕЛЕЗНОДОРОЖНЫЙ ТРАНСПОРТ ВОСТОКА РОССИИ В УСЛОВИЯХ ГРАЖДАНСКОЙ ВОЙНЫ}

\author{
Статья подготовлена в рамках поддержанного РФФИ научного проекта № 17-81-01023a(u) \\ «Гражданская война в Сибири в антропологическом, институциональном и геополитическом измерениях».

\begin{abstract}
На основе архивных материалов и периодической печати прослеживается управление железнодорожным транспортом на Урале, в Сибири, Степном крае и на Дальнем Востоке в антибольшевистский период Гражданской войны как фактор внутренней геополитики. Частные железные дороги получали государственные кредиты, что создало предпосылки для их выкупа казной в счет долга. Осуществлялось строительство новых железнодорожных линий, начатое до революции, продолженное Временным правительством и советской властью.

Ключевые слова: железные дороги; геополитика; хозяйственное освоение; Гражданская война; антибольшевистские правительства; Министерство путей сообщения; кредиты; национализация.
\end{abstract}

В мировой истории освоение пространства всегда происходило благодаря морским коммуникациям, а на континентальных просторах - речным путям. С изобретением железных дорог появилась возможность моделировать пространство, регулировать направление и густоту транспортной сети в интересах общества и государства. В европейской части Российской империи железнодорожное строительство в значительной мере обслуживало уже сформировавшиеся хозяйственные запросы, сокращая издержки по транспортировке пассажиров и товаров из зон избыточного производства до мест переработки или потребления.

На Урале, в Сибири и на Дальнем Востоке «стальные артерии» часто стимулировали освоение территории. Дополняя ориентированные в основном с юга на север речные пути, а кое-где и компенсируя полное их отсутствие, железные дороги почти целиком определяли обмен товарами с соседями, а потому часто задавали поселенческую структуру, создавали предпосылки не только для модернизации обжитых, но и для освоения новых пространств. В Азиатской России сложилось особое функциональное разделение государственных и частных инвестиций в строительство железных дорог. Казна принимала на себя основные расходы, осуществляя перспективное строительство с целью более плотного заселения и хозяйственного освоения новых пространств. Частные акционированные капиталы вкладывались в реализацию коммерчески оправданных проектов [1].

Хорошо известно, что революция, а затем Гражданская война сбили темп транспортного освоения азиатских просторов России, изменили его приоритеты, привели к смене модели организации железнодорожного строительства и обслуживания дорожного хозяйства. Вместо сложившегося до революции государственно-частного партнерства утвердилось полное огосударствление, централизация и жесткое планирование. В перспективе длинных трендов эту проблему основательно изучали $[2,3]$. Меньше внимания уделили хронологически короткому промежутку, являвшемуся «точкой перелома» между царским и советским периодами. Такое положение не кажется оправ- данным. Напротив, для дополнительного внимания к состоянию железных дорог востока России в указанный временной промежуток появились дополнительные основания. С военной точки зрения Гражданская война в значительной мере была борьбой за транспортные коммуникации, а боевые действия концентрировались вдоль них. Данное обстоятельство подчеркивает стратегическое значение железных дорог для противоборствовавших сторон.

Восточный фронт на протяжении длительного времени являлся главным фронтом Гражданской войны. На востоке России сформировалось Российское правительство, верховенство которого в антибольшевистском движении признавалось военными и политическими силами других окраинных центров: Юга, Севера-Запада и Севера России. Именно восточный лагерь контрреволюции продвинулся дальше всего на пути государственного строительства, восстановив и адаптировав к условиям Гражданской войны дореволюционные государственные и правовые институты. В полной мере это коснулось и транспортной политики. Для ее осуществления во второй половине 1918 1919 гг. действовала сеть правительственных органов и учреждений управления, финансирования и снабжения железных дорог, позволявших сочетать реагирование на непосредственные вызовы войны и перспективное планирование.

Значимость темы несущественно повлияла на степень ее изученности. Наиболее весомый вклад внесли статистики 1920-х гг., отразившие в своих небольших публикациях основные показатели технического состояния железных дорог Урала и Сибири в годы революции и Гражданской войны, динамику грузовых перевозок и темпы строительства новых железнодорожных линий $[4,5]$. В центре внимания советских историков долгое время находился только один, правда, важнейший аспект проблемы, связанный с установлением контроля союзников над Транссибирской магистралью [6-9]. В постсоветское время одни исследователи, продолжая советские традиции, сводили значение межсоюзных органов к механизму выкачки ресурсов с территории российского Дальнего Востока $[10,11]$. Другие авторы отметили позитивную роль 
союзников, ввели в научный оборот данные о международной технической поддержке российских железных дорог $[12,13]$. Стали изучаться и другие аспекты транспортной политики восточной контрреволюции. Исследователи обратили внимание на масштабные планы нового железнодорожного строительства, но лишь отчасти интересовались реальным положением железнодорожного хозяйства, ограничивая свое внимание узкими территориальными или хронологическими рамками [14-20].

Тематической узости способствовало состояние источников. В фондах Министерства путей сообщения Российского правительства не сохранились документы ни одного структурного подразделения, связанного с железными дорогами. Документация управлений отдельных железных дорог разбросана по разным архивам, но она позволяет реконструировать ситуацию только на местном уровне. Кроме того, делопроизводство железнодорожных предприятий относится к специальным. Оно изобилует техническими деталями, сложными для понимания. Упомянутую проблему частично позволяет преодолеть наличие фонда департамента железнодорожных дел Министерства финансов Российского правительства. Данное подразделение занималось вопросами финансирования частных железных дорог. Но помимо финансовых документов в него стекались сведения, необходимые для обоснования выделяемых дорогам кредитов, характеризующие многие аспекты железнодорожного хозяйства. Следует учесть, что в компетенцию департамента не входило регулирование проблем казенных железных дорог, соответственно, состояние ключевой магистрали в его материалах не отражено. Но обращение к архиву департамента позволяет решить две другие задачи. Во-первых, проследить порядок управления и финансирования частных железнодорожных предприятий, следовательно, понять, как строились взаимоотношения государства и частных владельцев; во-вторых, определить влияние Гражданской войны на эксплуатационные характеристики дорог и действия власти по поддержанию их в работоспособном состоянии.

Еще в конце XIX в. государство взяло курс на усиление контроля над частными железными дорогами. Сохранив гарантии выплаты акционерам твердых минимальных дивидендов, казна при этом требовала от акционерных обществ подчинения единым железнодорожным тарифам. Данное обстоятельство не умерило масштабы вложений частных капиталов в строительство новых железнодорожных магистралей, в том числе на Урале и за Уралом. Дополнительным ускорителем развития железнодорожного транспорта послужила Первая мировая война. Она выявила, в том числе, и узкие места транспортной сети, не позволявшие быстро наращивать вывоз ресурсов с Урала и из Сибири для снабжения продовольствием населения и фронта, сырьем - заводов Центральной России. В 1915 г. в строй были пущены Алтайская железная дорога с веткой от Барнаула до Бийска и строящейся веткой до Семипалатинска, отдельные участки Кольчугинской, в 1916 г. - Западно-Уральской, СевероВосточной, Уральской, Семиреченской, в 1917 г. -
Кулундинской, Ачинск-Абаканской железных дорог. Всего были сооружены линии протяженностью в 2521 версту [21. С. 314-319]. Особое междуведомственное совещание, созданное для выработки плана железнодорожного строительства, к январю 1917 г. наметило строительство в ближайшее пятилетие еще 5868 верст путей. Половина из них - разгрузочные дороги, пускающие грузы в обход Транссибирской магистрали, остальное - подъездные дороги в меридиальном направлении, включая дорогу Семипалатинск - Верный [22. С. 8-9]. Предполагалось резко увеличить участие казны в строительстве новых магистралей. Такие масштабные планы во многом связаны с тем, что в 1916 г. железные дороги Азиатской России вышли на максимальные за всю свою историю эксплуатационные показатели. Многие участки при этом работали с перегрузкой.

Дальнейшему наращиванию грузовых перевозок помешали революция и Гражданская война. Сведения о динамике товарных перевозок имеются не по всем железным дорогам восточных регионов России. В Сибири они составили 776 млн пудов в 1915 г. и 775 млн пудов в 1916 г., упали в 1917 г. до 631 млн пудов, в 1918 г. - до 469, в 1919 г. - до 352 млн пудов, т.е. сократились за три года вдвое. Такие показатели отражают серьезный кризис, но не крах железнодорожной отрасли. Следует учесть наличие в 1917 г. 20\% подвижного состава, требующего ремонта, тогда как в 1918 г. этот показатель вырос до 33\%, а в 1919 г. - до 40\% [4. С. 43, 49]. На дальневосточных железных дрогах этот показатель в 1917 г. составил 9,8\%, а в марте 1919 г. поднялся до 30\% [23. С. 29]. Таким образом, нагрузка на один исправно работавший паровоз и вагон понизилась не очень сильно.

Революция обернулась захватом дорог коллективами рабочих и служащих. На смену прежним управлениям отдельных дорог пришли дорожные комитеты. В результате к январю 1918 г. окончательно оформилась типологически единая структура коллегиальных органов самоуправления, одинаковая и для государственных и для частных дорог [24. С. 98]. Результатами деятельности дорожных комитетов стали падение производительности труда, расход казенных средств на потребительские нужды железнодорожников, реквизиция некоторых грузов и массовые хищение товаров из вагонов в связи с отсутствием должной охраны. Прервались взаиморасчеты между дорогами и предприятиями - поставщиками топлива и железнодорожного оборудования, что привело к серьезным финансовым и техническим проблемам в отрасли.

Смена власти в мае-августе 1918 г. оказалась не менее болезненной. Многие железнодорожники стали активными борцами за советскую власть, покинули свои рабочие места или подверглись репрессиям. При отступлении уводили подвижной состав, вывозили наличные суммы. На Западно-Уральской железной дороге Главный дорожный комитет при эвакуации изъял все принадлежавшие дороге средства [25. Д. 11. Л. 1-2].

После падения советской власти на востоке России начались возвращение прежней администрации, восстановление централизованного управления дорога- 
ми. Эта задача решалась легче на казенных железных дорогах. Правления частных дорог находились в Петрограде, и администрации, утратившие связь с ними, вынуждены были организовать восстановление работы дорог без соответствующих полномочий. Но даже на казенных дорогах Сибири администрация постепенно возобновила трудовую дисциплину и контроль над принятием кадровых решений, преодолевая сильное сопротивление профсоюзных организаций. На дорогах Поволжья, включая их уральские участки, до осени 1918 г. профессиональные железнодорожные союзы сохраняли весомую роль в принятии кадровых решений.

Урал до конца августа находился под управлением Временного областного правительства Урала. Но по соглашению между ним и Временным Сибирским правительством от 10 августа 1918 г. управление железными дорогами Урала передавалось сибирскому МПС [26. С. 16]. В действительности до конца августа никакого единого контроля над уральскими дорогами установлено не было. К концу лета 1918 г. в ведении Временного Сибирского правительства сосредоточились казенные железные дороги: Омская, Томская, Забайкальская, действующая частная Алтайская железная дорога и строящиеся Ачинск-Минусинская, Кольчугинская, Кулундинская, Южно-Сибирская. Осенью к ним добавились казенные дороги Дальнего Востока - Амурская, Уссурийская и акционерная КВЖД, а также частные железные дороги Урала Богословская, Волго-Бугульминская, Западно-Уральская, Северо-Восточная Уральская, Троицкая, частично Московско-Казанская, зимой 1918-1919 г - казенная Пермская. К началу 1919 г. общая протяженность железных дорог, находившихся в ведении Российского правительства, составила 17 тыс. верст действующих и 4818 верст строящихся [27. Л. 327-327 об.]. На всем протяжении дорог действовали единые ставки оплаты труда, общие правила взаимодействия профессиональных союзов, железнодорожной кооперации и администрации дорог, единый порядок финансирования. На рабочих и служащих казенных железных дорог распространялись все прибавки жалованья, как на других правительственных служащих [28. С. 160]. Частным железным дорогам средства перечислялись с расчетом, чтобы они могли выплачивать равные надбавки и своему персоналу [25. Д. 3; Л. 360; Д. 11. Л. 31-31 об.; 29. Д. 5. Л. 68; Д. 14. Л. 49].

В структуре Министерства путей сообщения (МПС) Временного Сибирского и Российского правительств пять из семи подразделений управляли железнодорожным хозяйством: департамент общих дел, эксплуатационный отдел, отдел строящихся железных дорог и отдел по восстановлению разрушенных путей, финансово-счетное управление. В октябре 1918 г. при Министерстве финансов был учрежден тарифный совет, регулировавший расценки на пассажирские и грузовые железнодорожные перевозки, и железнодорожный отдел (позже - департамент), контролировавший частные железные дороги. Распоряжениями МПС сначала на сибирских, а потом и на уральских дорогах ликвидировали все коллегиальные органы управления, восстанавливалось единоначалие (Цир- куляр МПС от 26 июня 1918 г.), упразднялись все созданные при советской власти подразделения (распоряжение управляющего МПС от 27 июня 1918 г.) и увольнялись все члены дорожных комитетов и советов (распоряжение товарища управляющего МПС от 16 июля 1918 г.) [27. Л. 183; 30. № 1-3. С. 4]. На Пермскую железную дорогу все распоряжения МПС распространились с 1 января 1919 г. [31].

3 июля 1918 г. Временное Сибирское правительство распорядилось по всем дорогам перейти на первоочередное обслуживание нужд армии. 5 июля 1918 г. на Самаро-Златоустовской дороге было введено военное положение [32. С. 161]. 15 июля 1915 г. его ввели на прифронтовых дорогах Сибири [33]. Железные дороги Урала с лета 1918 г. целиком перешли на обеспечение потребностей фронта. Коммерческое движение, активизировавшееся на Транссибе, на частных железных дорогах, кроме Алтайской, закрылось. Оставаясь формально самостоятельными предприятиями, они по части управления, выработки распорядка работ и ставок оплаты труда с конца сентября 1918 г. целиком подчинялись МПС Временного Сибирского, позже - Российского правительства. Продвигаясь на запад, войска Сибирской армии забирали для своих нужд все перевозочные средства дорог. Изменения боевой обстановки приводили к тому, что протяженность путей и количество дорожных служб под контролем управлений постоянно менялись, часть коммуникаций и сооружений разрушалась [25. Д. 19. Л. 3]. Важнейшей проблемой стало использование армией подвижного состава, топлива и прочих дорожных материалов без документального подтверждения. Составление сметы расходов прифронтовых дорог оказалось невозможным, и им приходилось запрашивать средства у казны на основании приблизительных калькуляций.

Стабилизация фронта в конце 1918 г. была относительной и недолгой. Уже 30 марта 1919 г. Верховный правитель утвердил положение по управлению железными дорогами в прифронтовом районе. Оно передавалось полевому управлению железных дорог театра военных действий, которое отвечало за эксплуатацию, ремонт и снабжение материалами всех железных дорог на театре военных действий. Руководители управления и отдельных участков дорог назначались МПС по согласованию со штабом Верховного главнокомандующего, получали от штаба задания на перевозки, согласовывали с ним все свои распоряжения [34. Л. 22-23]. Летом 1919 г. театром военных действий считались уральские железные дороги, со 2 сентября 1919 г. - Омская железная дорога. В начале осени рабочие и служащие уральских железных дорог были эвакуированы в Сибирь. Им выплачивались заработная плата и эвакуационные пособия, что легло тяжким непроизводительным бременем на правительственный бюджет [29. Д. 27. Л. 13, 57, 74, 167].

В экстремальных условиях Гражданской войны оптимальным решением для управлений частных железных дорог стали бы свертывание всякого строительства новых линий и сокращение расходов до минимума, необходимого для поддержания дороги в потенциально рабочем состоянии. Но именно обстоя- 
тельства военного времени этому мешали. Военные настаивали на ускоренном строительстве новых линий. Когда общество Троицкой железной дороги попыталось свернуть сооружение линии Троицк - Орск, то встретило категорические возражения со стороны правительства Оренбургского казачьего войска. Общество получило от Оренбургского казачьего войска 500 тыс. руб. и от Челябинского комитета народной власти 1 млн руб. на продолжение строительства [25. Д. 5. Л. 10-12]. Управление Западно-Уральской железной дороги также вынуждено было строить новые подъездные пути и разъезды по настоянию военных [Там же. Д. 11. Л. 11].

Не убавлялась и общественная коммерческая активность. В труднейшее время войны кооперация, органы местного самоуправления и биржевые комитеты проявили готовность вкладывать средства в строительство новых линий или достройку уже начатых при условии своевременного снабжения строительными материалами. В 1918-1919 гг. был выдвинут ряд проектов, перенацеливавших транспортную систему Сибири и Дальнего Востока на прямой вывоз ресурсов на внешние рынки, минуя Европейскую Россию. Их реализация позволяла использовать сибирские и дальневосточные богатства в интересах местного населения. Например, Южно-Сибирскую магистраль намеревались продолжить через Монголию, Манчжурию и российское Приморье на Посьет. Торгово-промышленники и кооператоры Степного края инициировали амбициозный проект прокладки магистрали от Кокчетава, через Петропавловск, Тобольск до устья Оби. Биржевые комитеты Екатеринбурга и ряда сибирских городов и земств настаивали на начале скорейших изысканий, связанных с прокладкой линии от Красноуфимска до Томска, которая открывала прямой путь для сибирских грузов к портам Белого моря. [25. Д. 14. Л. 1-3; Д. 23. Л. 29; Д. 37. Л. 12, 12-23 об.]. Ни одному из таких проектов не суждено было воплотиться [35. С. 5-8].

Однако продолжалось строительство тех линий, которое велось или было начато в 1916-1917 г. С июня 1918 г. по март 1919 г. на Урале и в Сибири уложили 762 версты новых путей, открыли для движения 569 верст, и это не считая ремонтных работ на действовавших линиях и прокладки на них новых подъездных путей [5. С. 40-43; 18. С. 84; 27. Л. 330]. Построенные ветки были небольшими по длине, имели направленность на вывоз хлеба, угля, металла и соли от мест производства и добычи к потребителям не только азиатской, но и европейской части России, таким образом, являлись вложениями в развитие инфраструктуры вывоза ресурсов.

В труднейших условиях Гражданской войны успешное продолжение строительства кажется почти невероятным. В действительности оно объяснялось несколькими обстоятельствами. Прежде всего, укладка рельсов велась «облегченным способом», без подготовки пути прямо на грунт. Стоимость такого строительства была в пять-восемь раз дешевле, чем укладка пути по всем правилам. Но и сооружали такие дороги как времянки, рассчитанные на эксплуатацию в течение одного - максимум двух лет [25. Д. 5.
Л. 194-196]. Упрощение технических условий применялось на строительстве новых путей в 1917 г. В последующие два года такая практика нашла еще более широкое применение.

В ряде случаев строительство являлось лишь продолжением работ, на которые последовательно выделяли средства царское, Временное и советское правительства. К таким следует отнести прокладку линии до Караталы Троицкой железной дороги, работы по подготовке строительства линии ПетропавловскКокчетав, строительство 160 верст путей на ЮжноСибирской железной дороге [5. С. 40, 42; 25. Д. 5. Л. 11-11 об., 42-45 об.].

Нельзя не упомянуть способность МПС централизовать ресурсы. Предприятия, выпускавшие рельсы, шпалы и иные железнодорожные материалы, остались в европейской части России. Запасы, имевшиеся у поволжских железных дорог, при отступлении Народной армии вывезти не удалось. Оставшиеся в распоряжении строившихся дорог материалы перераспределили между ними с учетом срочности ремонтных и строительных работ. В полном объеме заработали крупнейшие Омские, Красноярские и Владивостокские железнодорожные мастерские. Уральские предприятия, в частности Мотовилихинский завод, приспособили для ремонта паровозов, а УстьКатавский - для выпуска вагонов и запасных частей. На Усть-Катавском заводе к лету 1919 г. изготовили 371 вагон. Конечно, преобладала старая техника, вышедшая из ремонта. К 1 марта 1919 г. в сети железных дорог насчитывалось 97319 вагонов. Уральские заводы в первой половине 1919 г. поставили Министерству путей сообщения 420 тыс. пудов рельсов и еще почти 500 тыс. пудов других металлических материалов и запасных частей. Пропускная способность дорог по сравнению с осенними месяцами 1918 г. увеличилась на четверть [27. Л. 65-66об; 30. № 19. С. 13, 16; 36. Л. 65-66 об.; 37]. Удалось МПС и активизировать перевозку железнодорожных грузов из Владивостокского порта. За годы Первой мировой войны там скопились огромные запасы импортированных грузов на складах, включая рельсы и стрелки. Наконец, 18 марта 1919 г. Совет министров Российского правительства выделил 25 млн руб. для оплаты железнодорожного оборудования и материалов, приобретенных на Дальнем Востоке, в Японии и Америке [38. Ст. 176]. Нужду железных дорог в материалах МПС оценивало примерно в 400 млн руб., из которых упомянутые 25 млн руб. считались первоначальным оборотным капиталом. Для обеспечения составов топливом железнодорожный транспорт переводили на дрова и осуществляли централизованную разработку специально выделенных лесных участков [29. Д. 9. Л. 2; 37]. Все поставки проводились централизованно через отдел снабжения министерства и его дальневосточную и заграничную агентуру. Министерство определяло и приоритеты поставок разных видов оборудования и материалов [29. Д. 9. Л. 46, 55, 83-83 об., 91, 95, 97; 30. № 16-18. С. 1]. При этом строительство новых путей даже не являлось приоритетным. Более срочной считали работы по исправлению поврежденных войной коммуникаций. Одних только железнодо- 
рожных мостов к марту 1919 г. исправили 270 [27. Л. 328]. Российское правительство также финансировало заготовки продовольствия для железнодорожников, превратив дорожные потребительские кооперативы практически в бюджетные организации [39].

Важнейшим условием продолжения строительства стало также его финансирование из государственного бюджета. Казне пришлось взять на себя расходы частных железных дорог. Перечисление средств не могло производиться по смете МПС, как для казенных дорог Транссибирской магистрали. Все частные железнодорожные предприятия получили на льготных условиях коммерческие ссуды через специальный орган - Особое совещание по финансированию городских и земских самоуправлений и предприятий, имеющих общегосударственное значение. Из администрации частных дорог или даже их отдельных участков спешно создавались Временные правления. Российское правительство утверждало их в качестве органов, уполномоченных осуществлять коммерческие операции до того времени, пока не будет восстановлена связь с правлениями дорог постоянного состава.

Сохранились документы с запросами правлений частных дорог на оплату расходов. В них хорошо мотивирована и не вызвала сомнений сама необходимость правительственного субсидирования. Работа большинства дорог, за исключением Алтайской, Кольчугинской и строящейся Ачинск-Минусинской, целиком сводилась к обслуживанию нужд казны. К 22 ноября 1918 г. всем дорогам было выдано 48 млн 385 тыс. руб. 73\% отпущенной суммы шло на финансирование строительства новых путей и только 27\% - на эксплуатационные расходы. До конца года сумма должна была возрасти до 102 млн руб., из которых 62 млн руб. направлялись строительным управлениям, а 40 млн руб. - эксплуатационным [25. Д. 3. Л. 392-393]. Всего до марта 1920 г. по решениям Временного Сибирского и Российского правительств частным железным дорогам было выдано 305 млн 126 тыс. руб. [40. С. 207].

Условия финансирования частных железных дорог оказались предметом длительной бюрократической дискуссии. Железнодорожные акционерные общества получали ссуды под 7,5\% годовых. 19 мая 1919 г., опираясь на многочисленные ходатайства частных железнодорожных кампаний, МПС просило Министерство финансов сложить уплату процентов. Дороги обслуживали нужды казны, подчинялись общим убыточным железнодорожным тарифам. Прифронтовые дороги находились полностью в распоряжении военных. Получаемые ссуды не приносили владельцам прибыли, напротив, они не могли целиком покрыть убытки. Все это лишало государство оснований требовать начисления процентов за выданные ссуды. Но мнение Министерства финансов и Военного министерства оказалось другим. Оба настаивали на том, что государство в трудное время взяло на себя поддержание частных железных дорог в работоспособном состоянии и когда завершится Гражданская вой- на, справедливо будет потребовать от акционеров компенсации государственных расходов [25. Д. 3. Л. 348-349 об.]. Министерство финансов и Государственный контроль имели в руках многочисленные факты того, что подаваемые частными дорогами сметы составлялись по завышенным расценкам на работы и материалы [Там же. Д. 3. Л. 408-409, 415; Д. 13. Л. 41-41 об.; Д. 35. Л. 5-6]. Вероятно временные правления, лишенные возможности извлекать коммерческую выгоду из своей основной деятельности, пытались получить доходы от использования государственных кредитов.

Сам механизм финансирования частных железных дорог через коммерческие ссуды создавал правовые предпосылки для выкупа дорог казной. Утвержденные ссуды в первые месяцы выдавали под соловекселя правлений дорог. Но через некоторое время они консолидировались в залоговые обязательства и в дальнейшем производились только при условии передачи Государственному банку железнодорожных предприятий в качестве залогового обеспечения. Несвоевременная выплата начислений на ссуду или неправомерное ее расходование оказывались достаточным основанием для перехода имущества частных дорог в распоряжение казны [25. Д. 3. Л. 47, 51, 71]. К концу зимы 1919 г. в отделениях государственного банка и железнодорожном департаменте Министерства финансов находилось 59 залоговых обязательств практически всех частных железнодорожных предприятий востока России на общую сумму 103856 тыс. руб. [Там же. Л. 309-309 об.]. Суммы кредитов по каждой железной дороге оказались достаточно велики, чтобы превратить их в безнадежных банкротов, и почти неизбежно предопределить их переход в собственность государства.

Несомненно, что Гражданская война обернулась технической деградацией железнодорожного хозяйства, пик кризиса которого пришелся на послевоенные годы. Но важно за этой технической стороной проблемы увидеть другую, организационную. Не отказываясь в перспективе от участия частного капитала в строительстве и эксплуатации железных дорог, Временное Сибирское и Российское правительства сделали решительный шаг по пути установления почти полного хозяйственного и финансового контроля над уже существовавшими частными железнодорожными предприятиями. Новое железнодорожное строительство и при советской власти в конце 1917 первой половине 1918 г., и при их противниках в значительной мере шло «по инерции» в рамках намеченных до революции приоритетов и направлений. Но от проектов освоения таежных и приарктических сибирских пространств пришлось отказаться. Они оказались не по силам и советской власти в два последующих десятилетия. Война не помешала, однако, успешному строительству «коротких» магистралей, способствовавших освоению полезных ископаемых и использованию избыточных сельскохозяйственных ресурсов горной и степной зон Южного и Среднего Урала, Южной Сибири и Степного края.

\section{ЛИТЕРАТУРА}

1. Баталова Т.И. Территориальное размещение частных железных дорог Азиатской России и политика государства // Региональные особенности управления государственным хозяйством России XVIII - начала XX в. : материалы Всерос. науч. конф. Томск, 2007. С. 134-141. 
2. Ламин В.А., Пленкин В.Ю., Ткаченко В.Я. Глобальный трек: развитие транспортной системы на востоке страны. Екатеринбург, 1999.199 с.

3. Тимошенко А.И. Транссиб и проекты железнодорожного строительства в Сибири // Гуманитарные науки в Сибири. 2000. № 2. С. 71-74.

4. Мерхалев Д. Железные дороги Сибири в 1917-1919 гг. // Сборник сибирского краевого статистического управления. Новониколаевск, 1922. Т. 2. С. 41-51.

5. Пинус В. Железнодорожное строительство Сибири за пятилетие 1918-1922 гг. // Жизнь Сибири. 1922. № 3. С. 40-42.

6. Крушанов А.И. К вопросу о роли Межсоюзного комитета и Технического совета в осуществлении империалистических планов США и Японии на Дальнем Востоке и в Сибири в 1918-1919 гг. // Ученые записки Дальневосточного университета. Вып. 2. Сер. обществ.полит. наук. Владивосток, 1958. С. 69-78.

7. Крушанов А.И. О роли Межсоюзного комитета и Технического совета в осуществлении империалистических планов США и Японии на Дальнем Востоке и в Сибири в 1918-1919 гг. // Труды ДВ филиала СО АН СССР. Сер. История. Т. 2. 1961. С. 15-20.

8. Попова Е.И. Миссия Стивенса и провал железнодорожной политики США в России и Китае в 1917-1922 // Исторические записки. М., 1957. Т. 60. С. $31-85$.

9. Индукаева Н.С. Борьба американской дипломатии за установление межсоюзнического контроля на КВЖД (1918 - март 1919 г.) // Сборник научных трудов исторических кафедр. Труды ТГУ. Томск : Из-во ТГУ, 1963. Т. 171. С. 94-101.

10. Гнатовская Е.Н. Из истории железнодорожной политики США на Дальнем Востоке. 1917-1920 гг. // III дальневосточная конференция молодых историков. Владивосток, 1994. С. 68-69.

11. Мухачев Б.И. К вопросу о деятельности Межсоюзного железнодорожного комитета на Дальнем Востоке (1918-1922 гг.) // КВЖД и ее влияние на развитие политических, социально-экономических и культурных процессов в Северо-Восточной Азии : тезисы докл. и собщ. науч. конф. Владивосток, 1997. С. 45-47.

12. Дмитриев Н.И. Межсоюзный железнодорожный комитет и его роль в восстановлении Сибирской магистрали в 1919 г. // Гражданская война на Дальнем Востоке России: итоги и уроки : тезисы Междунар. науч. конф. Владивосток, 1992. С. $45-47$.

13. Дмитриев Н.И., Дмитриева Т.В. Междусоюзный железнодорожный комитет и его роль в восстановлении Сибирской магистрали // Фундаментальные и прикладные исследования по транспорту. Вып. 24 (106). Страницы истории России : сб. науч. тр. Екатеринбург, 2002. C. $142-155$.

14. Гнатовская Е.Н. Состояние железнодорожного транспорта и положение рабочих на Дальнем Востоке в $1918-1922$ гг. // Исторический опыт освоения восточных районов России : материалы Междунар. науч-практ. конф. Владивосток, 1993. Кн. III. С. 49-52.

15. Гнатовская Е.Н. Железные дороги как фактор экономической и геополитической стратегии России на Дальнем Востоке (конец ХІХ первые десятилетия ХХ в.) // Гуманитарные исследования : сб. науч. статей. Уссурийск, 1999. Вып. 3. С. $276-282$.

16. Коновалов П.С. Строительство и эксплуатация Ачинск-Минусинской железной дороги (1914-1920 гг.) // Хозяйственное освоение Сибири: вопросы истории XIX - первой трети XX в. : сб. науч. статей. Томск, 1994. С. 49-60.

17. Дмитриев Н.И. Железные дороги востока России в начальный период Гражданской войны // Пути сообщения, коммуникации, научные достижения народов Евразии : материалы Междунар. науч.-практ. конф. Березники, 1997. С. 110-113.

18. Дмитриев Н.И. Новое железнодорожное строительство в Сибири при Российском правительстве адмирала А.В. Колчака // История «белой» Сибири : тезисы Второй науч. конф. Кемерово, 1997. С. 81-84.

19. Ижендеев А.Ю. Управление Томской железной дороги в 1917-1920 гг. // Вестник Томского государственного университета. 2011. № 353. С. 77-80.

20. Климов И.П. Деятельность правительств демократической контрреволюции Сибири и Урала на железнодорожном и водном транспорте весной - осенью 1918 года // Новейшая история России. 2017. № 2. С 53-67.

21. История железнодорожного транспорта России. Т. 1: 1836-1917 гг. СПб., 1994. 336 с.

22. План железнодорожного строительства в Сибири на ближайшее десятилетие. Пг., 1917. С. 79.

23. Доклады Приморской окружной торгово-промышленной палаты по вопросам экономики русского Дальнего Востока, представленные на Вашингтонскую конференцию 1921 года. Владивосток, 1922. 459 с.

24. Сенин А.С. Борьба за власть на российских железных дорогах: Викжель Викжедор, Всопрофжель... // Новый исторический вестник. 2005. № 13. С. 96-141.

25. Государственный архив Омской области (далее - ГАОО). Ф. Р-1858. Железнодорожный отдел Министерства финансов Российского правительства. Оп. 1.

26. Колчаковщина на Урале (1918-1919 гг.) в документах и материалах с вводным очерком А. Танеева. Свердловск, 1929. 233 с.

27. Государственный архив Российской Федерации (далее - ГАРФ). Ф. Р-341. Политический центр. Оп. 1. Д. 39.

28. Вестник Омской железной дороги. Омск, 1919. № 15-16.

29. ГАОО. Ф. Р-1181. Финансово-счетное управление Министерства путей сообщения Российского правительства. Оп. 1.

30. Вестник Министерства путей сообщения. Омск, 1919.

31. Отечественные ведомости. Екатеринбург, 1919. 30 марта.

32. Вестник Самаро-Златоустовской железной дороги. Самара, 1918. № 11-13.

33. Правительственный вестник. Омск, 1918. 16 августа.

34. ГАОО. Ф. 2045. Управление Омской железной дороги Министерства путей сообщения Российского правительства. Оп 1. Д. 1.

35. Рынков В.М. Сибирская автономия в вихре Гражданской войны // Сибирь: проекты ХХ века (начинания и реальность) : сб. науч. статей. Новосибирск, 2000. Вып 4. С. 3-25.

36. ГАРФ. Ф. Р-176. Совет министров Российского правительства. Оп. 4. Д. 34. Л. 65-66 об.

37. Вестник Приуралья. Челябинск, 1919. 2 июля.

38. Собрание узаконений и постановлений Российского правительства издаваемое при Правительствующем сенате. Омск, 1919. № 11.

39. Русская армии. Ново-Николаевск, 1919. 7 марта.

40. Рынков В.М. Финансовая политика антибольшевистских правительств востока России (вторая половина 1918 - начало 1920 гг.). Новосибирск, 2006. С. 440.

Статья представлена научной редакцией «История» 17 декабря 2017 г.

\section{GEOPOLITICAL CHALLENGES AND MODERNISATION RESPONSES: RAILWAY TRANSPORT IN THE EAST OF RUSSIA UNDER THE CONDITIONS OF THE RUSSIAN CIVIL WAR}

Vestnik Tomskogo gosudarstvennogo universiteta - Tomsk State University Journal, 2018, 428, $175-182$.

DOI: $10.17223 / 15617793 / 428 / 23$

Vadim M. Rynkov, Institute of History, Siberian Branch Russian Academy of Science (Novosibirsk, Russian Federation). E-mail: vadsvet@list.ru

Keywords: railroad communications; geopolitics; development; Civil War; anti-Bolshevist governments; Ministry of Railways; credits; nationalization.

The article deals with the peculiarities of railway management in the Asian part of Russia in the days of anti-Bolshevist governments. The material is presented within the broad context of railroad construction history. The main railway lines constructed by the 
state before the revolution of 1917 in the Asian part of Russia led to the territory development. Private funds were invested in the warrantable projects. The Civil War mostly went along the railroads situated in the East of Russia. It is not unexpected that railway economy incurred substantial costs and, at the same time, railroads became a guide to the source of almost all the goods for the army and citizens. The state of the railway transport in the East of Russia was researched fragmentarily or formally and on the basis of fragmentary data. The author introduces documents of the Railway Department of the Ministry of Finance of the Russian Government and materials of periodical press into scientific use. The author considers it necessary to point out that laying train tracks in the Asian part of Russia was enhanced by private companies before the revolution. At the same time, the state recognized the importance of creation of a single plan of train tracks development, prioritizing and investments in laying train tracks. But the Civil War temporarily disorganized the unity of administration, and transfer of the railroads to railway committees made them unprofitable. Since the autumn of 1918, the Ministry of Railways of the Provisional Siberian Government and All-Russian Government managed to reconstruct the unity of administration and financing of all the state-owned and private railroads of the Urals, Siberia, the Steppe and the Far East. As shown in some sources researched by the author the Ministry used the sources of rail materials effectively, organized manufacturing of new carriages and spare parts in the Urals, which helped restore the damaged communications and build about 505 miles of new railway lines. The Ministry had to abandon the ambitious prerevolutionary plans of railway lines construction in the taiga zone of Siberia, but it continued construction of short railway lines that connected Siberian extractive industries with the TransSiberian Railway and the lines that delivered grain from Siberia. Construction of new railway lines and exploitation costs of private railway companies were paid from the funds of the Provisional Siberian and All-Russian Governments. The companies applied for a loan upon the security of the enterprises to the State bank, and it resulted in the transfer of private railroads of the eastern regions of Russia to the state. New railway construction continued within the frame of prerevolutionary directions and priorities. But the authorities had to put an end to the projects of the taiga and subarctic territories.

\section{REFERENCES}

1. Batalova, T.I. (2007) [Territorial location of private railways in Asian Russia and state policy]. Regional'nye osobennosti upravleniya gosudarstvennym khozyaystvom Rossii XVIII - nachala XX v. [Regional features of management of the state economy of Russia in the 18th - early 20th centuries]. Proceedings of the conference. Tomsk. pp. 134-141. IORR

2. Lamin, V.A., Plenkin, V.Yu. \& Tkachenko, V.Ya. (1999) Global'nyy trek: razvitie transportnoy sistemy na vostoke strany [Global track: the development of the transport system in the east of the country]. Ekaterinburg: UrB RAS.

3. Timoshenko, A.I. (2000) Transsib i proekty zheleznodorozhnogo stroitel'stva v Sibiri [Transsib and projects of railway construction in Siberia]. Gumanitarnye nauki $v$ Sibiri - Humanitarian sciences in Siberia. 2. pp. 71-74.

4. Merkhalev, D. (1922) Zheleznye dorogi Sibiri v 1917-1919 gg. [Railroads of Siberia in 1917-1919]. In: Sbornik sibirskogo kraevogo statisticheskogo upravleniya [The collection of the Siberian regional statistics administration]. Vol. 2. Novonikolaevsk: Tipografiya Gubsovnarkhoza 1.

5. Pinus, V. (1922) Zheleznodorozhnoe stroitel'stvo Sibiri za pyatiletie 1918-1922 gg. [Railroad construction of Siberia in the five-year period 19181922]. Zhizn'Sibiri. 3. pp. 40-42.

6. Krushanov, A.I. (1958) K voprosu o roli Mezhsoyuznogo komiteta i Tekhnicheskogo soveta v osushchestvlenii imperialisticheskikh planov SShA i Yaponii na Dal'nem Vostoke i v Sibiri v 1918-1919 gg. [On the role of the Inter-Union Committee and the Technical Council in the implementation of the US and Japanese imperialist plans in the Far East and Siberia in 1918-19]. Uchenye zapiski Dal'nevostochnogo universiteta. 2. pp. 69-78.

7. Krushanov, A.I. (1961) O roli Mezhsoyuznogo komiteta i Tekhnicheskogo soveta v osushchestvlenii imperialisticheskikh planov SShA i Yaponii na Dal'nem Vostoke i v Sibiri v 1918-1919 gg. [On the role of the Inter-Union Committee and the Technical Council in the implementation of the imperialist plans of the United States and Japan in the Far East and Siberia in 1918-1919]. Trudy DV filiala SO AN SSSR. Ser. Istoriya. 2. pp. $15-20$.

8. Popova, E.I. (1957) Missiya Stivensa i proval zheleznodorozhnoy politiki SShA v Rossii i Kitae v 1917-1922 [Stevens mission and the failure of the US railway policy in Russia and China in 1917-1922]. Istoricheskie zapiski. 60. pp. 31-85.

9. Indukaeva, N.S. (1963) Bor'ba amerikanskoy diplomatii za ustanovlenie mezhsoyuznicheskogo kontrolya na KVZhD (1918 - mart 1919 g.) [The struggle of American diplomacy for establishing inter-allied control on the CER (1918 - March 1919)]. Sbornik nauchnykh trudov istoricheskikh kafedr. Trudy TGU. 171. pp. 94-101.

10. Gnatovskaya, E.N. (1994) [From the history of the US railroad policy in the Far East. 1917-1920]. III Far Eastern Conference of Young Historians. Vladivostok. pp. 68-69. (In Russian).

11. Mukhachev, B.I. (1997) [On the issue of the activities of the Inter-Union Railway Committee in the Far East (1918-1922)]. KVZhD i ee vliyanie na razvitie politicheskikh, sotsial'no-ekonomicheskikh $i$ kul'turnykh protsessov v Severo-Vostochnoy Azii [The CER and its influence on the development of political, socio-economic and cultural processes in Northeast Asia]. Proceedings of the conference. Vladivostok. pp. 45-47. (In Russian).

12. Dmitriev, N.I. (1992) [The Inter-Union Railway Committee and its role in rebuilding the Siberian Railway in 1919]. Grazhdanskaya voyna na Dal'nem Vostoke Rossii: itogi i uroki [The Civil War in the Far East of Russia: Results and Lessons]. Proceedings of the international conference. Vladivostok. pp. 45-47. (In Russian).

13. Dmitriev, N.I. \& Dmitrieva, T.V. (2002) Mezhdusoyuznyy zheleznodorozhnyy komitet i ego rol'v vosstanovlenii Sibirskoy magistrali [The InterUnion Railway Committee and its role in the reconstruction of the Siberian Railway]. Fundamental'nye i prikladnye issledovaniya po transportu. 24 (106). pp. 142-155.

14. Gnatovskaya, E.N. (1993) [The state of railway transport and the situation of workers in the Far East in 1918-1922]. Istoricheskiy opyt osvoeniya vostochnykh rayonov Rossii [Historical experience of the development of the eastern regions of Russia]. Proceedings of the international conference. Book 3. Vladivostok. pp. 49-52. (In Russian).

15. Gnatovskaya, E.N. (1999) Zheleznye dorogi kak faktor ekonomicheskoy i geopoliticheskoy strategii Rossii na Dal'nem Vostoke (konets XIX pervye desyatiletiya XX v.) [Railways as a factor in the economic and geopolitical strategy of Russia in the Far East (late 19th - first decades of the 20th centuries)]. In: Gumanitarnye issledovaniya [Humanities Research]. Is. 3. Ussuriysk: USPI. pp. 276-282.

16. Konovalov, P.S. (1994) Stroitel'stvo i ekspluatatsiya Achinsk-Minusinskoy zheleznoy dorogi (1914-1920 gg.) [Construction and operation of the Achinsk-Minusinsk railway (1914-1920)]. In: Zinov'ev, V.P. (ed.) Khozyaystvennoe osvoenie Sibiri: voprosy istorii XIX - pervoy treti XX v. [Economic development of Siberia: issues of the history of the 19th - first third of the 20th centuries]. Tomsk: Tomsk State University.

17. Dmitriev, N.I. (1997) [The railways of the east of Russia in the initial period of the Civil War]. Puti soobshcheniya, kommunikatsii, nauchnye dostizheniya narodov Evrazii [Ways of communication, communications, scientific achievements of the peoples of Eurasia]. Proceedings of the international conference. Berezniki. pp. 110-113. (In Russian).

18. Dmitriev, N.I. (1997) [The new railway construction in Siberia under the Russian government of Admiral A.V. Kolchak]. Istoriya "beloy" Sibiri [History of the "white" Siberia]. Proceedings of the conference. Kemerovo. pp. 81-84. (In Russian).

19. Izhendeev, A.Yu. (2011) Administration of Tomsk railroad in 1917-1920. Vestnik Tomskogo gosudarstvennogo universiteta - Tomsk State University Journal. 353. pp. 77-80. (In Russian). 
20. Klimov, I.P. (2017) "Democratic Counter-revolution" Governments of Siberia and Ural and their Activity on Railways and Water Transport in Spring and Autumn of 1918. Noveyshaya istoriya Rossii-Modern History of Russia. 2. pp. 53-67. (In Russian).

21. Kraskovskiy, E.Ya. \& Uzdin, M.M.(eds) (1994) Istoriya zheleznodorozhnogo transporta Rossii [History of railway transport in Russia]. Vol. 1: 1836-1917. St. Petersburg: Ivan Fedorov.

22. Anon. (1917) Plan zheleznodorozhnogo stroitel'stva v Sibiri na blizhayshee desyatiletie [Plan for railway construction in Siberia for the next decade]. Petrograd: Sadovaya tipo-lit. N.G. Mazur.

23. Primorsky District Chamber of Commerce and Industry. (1922) Doklady Primorskoy okruzhnoy torgovo-promyshlennoy palaty po voprosam ekonomiki russkogo Dal'nego Vostoka, predstavlennye na Vashingtonskuyu konferentsiyu 1921 goda [Reports of the Primorsky District Chamber of Commerce and Industry on the economy of the Russian Far East, presented at the Washington Conference in 1921]. Vladivostok: Izd. Prim. okruzhnoy Torgovo-promyshl. palaty.

24. Senin, A.S. (2005) Bor'ba za vlast' na rossiyskikh zheleznykh dorogakh: Vikzhel' Vikzhedor, Vsoprofzhel'... [Struggle for power on the Russian railways: Vikzhel Vikzhedor, Vsoprofzhel ... . Novyy istoricheskiy vestnik. 13. pp. 96-141.

25. State Archive of Omsk Oblast (GAOO). Fund R-1858. Zheleznodorozhnyy otdel Ministerstva finansov Rossiyskogo pravitel'stva [Railway Department of the Ministry of Finance of the Russian Government]. List 1.

26. Uralprofsovet. (1929) Kolchakovshchina na Urale (1918-1919 gg.) v dokumentakh i materialakh s vvodnym ocherkom A. Taneeva [Kolchakism in the Urals (1918-1919) in documents and materials with an introductory essay by A. Taneev]. Sverdlovsk: Izdanie Uralprofsoveta.

27. State Archive of the Russian Federation (GARF). Fund R-341. Politicheskiy tsentr [Political Center]. List 1 . File 39.

28. Vestnik Omskoy zheleznoy dorogi. (1919). 15-16.

29. State Archive of Omsk Oblast (GAOO). Fund R-1181. Finansovo-schetnoe upravlenie Ministerstva putey soobshcheniya Rossiyskogo pravitel'stva [Financial Accounting Department of the Ministry of Railways of the Russian Government]. List 1.

30. Vestnik Ministerstva putey soobshcheniya. (1919).

31. Otechestvennye vedomosti. (1919). 30 March.

32. Vestnik Samaro-Zlatoustovskoy zheleznoy dorogi. (1918). 11-13.

33. Pravitel'stvennyy vestnik. (1918). 16 August.

34. State Archive of Omsk Oblast (GAOO). Fund 2045. Upravlenie Omskoy zheleznoy dorogi Ministerstva putey soobshcheniya Rossiyskogo pravitel'stva [Office of the Omsk Railway Ministry of Railways of the Russian Government]. List 1. File 1.

35. Rynkov, V.M. (2000) Sibirskaya avtonomiya v vikhre Grazhdanskoy voyny [Siberian autonomy in the whirlwind of the Civil War]. In: Lamin, V.A. (ed.) Sibir': proekty XX veka (nachinaniya i real'nost') [Siberia: projects of the 20th century (startups and reality)]. Is. 4. Novosibirsk: IH SB RAS.

36. State Archive of the Russian Federation (GARF). Fund R-176. Sovet ministrov Rossiyskogo pravitel'stva [Council of Ministers of the Russian Government]. List 4. File 34. Pages 65-66 rev.

37. Vestnik Priural'ya. (1919). 2 July.

38. Russian Government. (1919) Sobranie uzakoneniy i postanovleniy Rossiyskogo pravitel'stva izdavaemoe pri Pravitel'stvuyushchem senate [Collection of laws and regulations of the Russian government published at the Governing Senate]. 11.

39. Russkaya armiya. (1919). 7 March.

40. Rynkov, V.M. (2006) Finansovaya politika antibol'shevistskikh pravitel'stv vostoka Rossii (vtoraya polovina 1918 - nachalo 1920 gg.) [The financial policy of the anti-Bolshevik governments of the east of Russia (second half of 1918 - early 1920s)]. Novosibirsk: IH SB RAS.

Received: 17 December 2017 